IZA DP No. 7777

Distributional Effects of Macroeconomic Policy Choices in Emerging Market Economies

Eswar S. Prasad

November 2013 


\title{
Distributional Effects of Macroeconomic Policy Choices in Emerging Market Economies
}

\author{
Eswar S. Prasad \\ Cornell University, \\ Brookings Institution, NBER and IZA
}

Discussion Paper No. 7777

November 2013

\author{
IZA \\ P.O. Box 7240 \\ 53072 Bonn \\ Germany \\ Phone: +49-228-3894-0 \\ Fax: +49-228-3894-180 \\ E-mail: iza@iza.org
}

\begin{abstract}
Any opinions expressed here are those of the author(s) and not those of IZA. Research published in this series may include views on policy, but the institute itself takes no institutional policy positions. The IZA research network is committed to the IZA Guiding Principles of Research Integrity.

The Institute for the Study of Labor (IZA) in Bonn is a local and virtual international research center and a place of communication between science, politics and business. IZA is an independent nonprofit organization supported by Deutsche Post Foundation. The center is associated with the University of Bonn and offers a stimulating research environment through its international network, workshops and conferences, data service, project support, research visits and doctoral program. IZA engages in (i) original and internationally competitive research in all fields of labor economics, (ii) development of policy concepts, and (iii) dissemination of research results and concepts to the interested public.
\end{abstract}

IZA Discussion Papers often represent preliminary work and are circulated to encourage discussion. Citation of such a paper should account for its provisional character. A revised version may be available directly from the author. 


\section{ABSTRACT}

\section{Distributional Effects of Macroeconomic Policy Choices in Emerging Market Economies ${ }^{1}$}

Distributional consequences typically receive limited attention in economic models that analyze the effects of monetary and financial sector policies. These consequences deserve more attention since financial markets are incomplete, imperfect, and economic agents' access to them is often limited. This limits households' ability to insure against householdspecific (or sector-specific) shocks and magnifies the distributional effects of aggregate macroeconomic fluctuations and associated policy responses. These effects are likely to be even larger in emerging market and low-income economies beset by financial frictions. The political economy surrounding distributional consequences can sometimes lead to policy measures that reduce aggregate welfare. I argue that it is important to take better account of distributional rather than just aggregate consequences when evaluating specific policy interventions as well as the mix of different policies.

JEL Classification: E5, E6, F4

Keywords: income and wealth distribution, inequality, emerging markets, financial frictions, monetary policy, macroeconomic policies

Corresponding author:

Eswar Prasad

Cornell University

Dyson School of Applied Economics and Management

440 Warren Hall

Ithaca, NY 14853

USA

E-mail: eswar.prasad@cornell.edu

\footnotetext{
1 This paper is based on a keynote lecture delivered by the author at the Bank of Korea-IMF Conference on "Asia: Challenges of Stability and Growth" Seoul, September 26-27, 2013. The author is grateful to Olivier Blanchard, Pierre-Olivier Gourinchas, M. Ayhan Kose, and numerous conference participants for their insightful comments and observations on earlier drafts. The author also thanks Abigail Warren for useful editorial comments.
} 


\section{NON-TECHNICAL SUMMARY}

Policy choices have distributional consequences. This proposition is seen as self-evident in the context of certain macroeconomic policies such as fiscal policy that often have an explicit redistributive element. However, far less attention has been paid to the distributional consequences of a range of other macroeconomic and structural policies, with much of the analysis in the academic literature typically focused on aggregate consequences, especially in terms of growth and volatility.

This paper argues that a broad range of macroeconomic policies - especially those related to monetary policy and financial regulation - can also have significant distributional consequences. The reason is that financial markets are incomplete, imperfect (e.g., due to information asymmetries), and economic agents' access to them is often limited. Consequently, households cannot effectively insure against the asymmetric effects of such policies.

In emerging markets and low-income economies, underdeveloped financial markets, coupled with insufficient access to formal financial institutions, limit households' ability to insure against idiosyncratic (household-specific) shocks and magnify the distributional effects of aggregate macroeconomic fluctuations that may initially have only small effects.

While distributional consequences of policies are of intrinsic interest, a related and equally important question is whether these consequences in turn determine the choice of policy responses to specific shocks. Such choices, which often reflect the relative political power of different groups, can sometimes have deleterious aggregate consequences.

I argue that it is important to explicitly recognize distributional rather than just aggregate consequences when evaluating specific policy interventions as well as the mix of different policies. This does not mean, for instance, that central bankers should include measures of inequality in their operating rules. Rather, it is a call for a more careful evaluation of welfare consequences of policies that do not just focus on aggregate outcomes. 


\section{Introduction}

Policy choices have distributional consequences. This proposition is seen as self-evident in the context of certain macroeconomic policies such as fiscal policy that often have an explicit redistributive element. However, far less attention has been paid to the distributional consequences of a range of other macroeconomic and structural polices, with much of the analysis in the academic literature typically focused on aggregate consequences, especially in terms of growth and volatility.

Distributional consequences typically receive limited attention in economic models that analyze the effects of monetary policies or specific interventions such as capital controls. In a world with complete financial markets, this is usually not a first order issue as monetary policy then affects macroeconomic variables such as inflation and growth but has few distributional consequences. If households can fully insure against householdspecific income risk, then particular policy choices may have aggregate welfare consequences but limited distributional consequences. The reality is of course quite different. Financial markets are incomplete (in the Arrow-Debreu sense), imperfect (e.g., due to information asymmetries), and economic agents' access to them is often limited.

A burgeoning literature has begun to formally tackle the distributional effects of conventional and unconventional monetary policy actions in advanced economies. Even in a simplistic setting in which changes in policy interest rates are the main tool of monetary policy, such changes can have differential impacts on net borrowers relative to net savers. If households can insure completely against this source of income risk, then the distributional effects would be muted. However, such markets do not exist even in rich economies that have well-developed financial systems.

In emerging markets and low-income economies, underdeveloped financial markets, coupled with insufficient access to formal financial institutions, limit households' ability to insure against idiosyncratic (household-specific) shocks and magnify the distributional effects of aggregate macroeconomic fluctuations that may initially have only small 
effects. In many of these economies, only a relatively small proportion of households have access to the formal financial sector. On average, more than half of the population in emerging markets lacks access to the formal financial system. ${ }^{2}$ By contrast, in advanced economies, nearly all households have such access. Furthermore, many households in emerging market economies conduct most of their financial transactions using cash and have little access to alternative mechanisms for insuring against household-specific income risk. All of these factors are likely to increase the distributive impact of macroeconomic shocks and stabilization policies in these economies, generating first-order welfare consequences.

This paper is not concerned with structural shifts such as technological change and associated shifts in the bargaining power between labor and capital that drive persistent changes in inequality. ${ }^{3}$ However, the separation between short-term fluctuations and long-term trends is sometimes not clear-cut. For instance, extreme events such as financial crises can have short-term as well as long-lasting effects in terms of the distribution of income and wealth in an economy.

Crises tend to have asymmetric effects on households at different parts of the income distribution. There is a long literature suggesting that crises, and even deep recessions, can have larger and more persistent adverse welfare consequences for unskilled workers and, more generally, for the poor. ${ }^{4}$ The newer (and still quite limited) literature discussed in this paper makes the point that it is not only recessions and crises themselves but also the policies adopted to counteract these adverse macroeconomic events that can have significant distributional effects.

\footnotetext{
${ }^{2}$ See Demirguc-Kunt and Klapper (2012) for cross-country data on financial inclusion. More cross-country data is available through the IMF's Financial Access Survey at http://fas.imf.org ${ }^{3}$ See Piketty and Saez (2013a) for a discussion of these issues in the context of the U.S.

${ }^{4}$ Baldacci, de Mello, and Inchauste (2002) show that balance of payments and banking crises lead to large increases in poverty and income inequality. Recent studies include Dao and Loungani (2010), who examine the labor market consequences of recessions in advanced economies and show that these effects can be long-lasting. Van Dijk (2013) shows that banking crises also have large social costs, including adverse effects on health, education, and poverty. These effects of crises are more pronounced in less-developed countries.
} 
While distributional consequences of policies are of intrinsic interest, a related and equally important question is whether these consequences in turn determine the choice of policy responses to specific shocks. Such choices, which often reflect the relative political power of different groups, can sometimes have deleterious aggregate consequences. Certain policies can have significant implications for small but politically powerful groups; these effects can be in a direction opposite to that of the general welfare effects. This is well recognized in trade theory, for instance, where the benefits of free trade are distributed broadly amongst the population but the costs of opening up to foreign competition are borne by a relatively small group. In the absence of redistributive mechanisms that mitigate the losses of those hurt by more open trade, the political clout of the potential losers can lead to policy choices that have adverse aggregate welfare consequences. The insider-outsider theory of labor markets, where political capture by insiders can lead to adverse employment consequences, is another example of a distributional issue having aggregate effects.

For emerging market economies dealing with monetary and other macroeconomic policy choices, these issues turn out to be equally important. In this paper, I argue that it is important to explicitly recognize distributional rather than just aggregate consequences when evaluating specific policy interventions as well as the mix of different policies. This does not mean, for instance, that central bankers should include measures of inequality in their operating rules. Rather, it is a call for a more careful evaluation of welfare consequences of policies that do not just focus on aggregate outcomes.

Distributional issues have become especially relevant in light of rising financial integration and policy developments in advanced economies since the financial crisis. In advanced economies, monetary policy has become the main line of defense against macroeconomic shocks. With their economies becoming increasingly complex and more financially open, monetary policy has also moved to the center stage in the policy toolkit of developing economies (a term encompassing emerging market and less-developed economies). The range of conventional and unconventional monetary policy actions employed by central banks around the world has expanded, necessitating an analytical 
reexamination of more than just the aggregate effects of these policies.

Existing analytical frameworks are inadequate for addressing some of these issues in a satisfactory manner. Monetary policy analysis for developing economies has traditionally been conducted with open economy extensions of models that are mainly relevant for advanced economies. Emerging market economies have certain structural features that cannot be easily captured in such models. Incomplete and underdeveloped financial markets, low levels of financial access, and weak monetary transmission mechanisms are among the features that are typical to emerging markets and less developed economies, and that deserve more careful attention in formal models.

I first provide a selective overview of the existing literature on the distributional consequences of a variety of macroeconomic policies. This overview focuses on policies that have distributional consequences from a short-term or business cycle perspective rather than on the determinants of longer-term changes in income and wealth inequality. I then briefly review two recent pieces of work that attempt to address this topic in formal theoretical settings. That is followed by a discussion of what dimension of heterogeneity seems to matter most for assessing welfare consequences of different policies. Finally, I review some broader policy issues relevant to emerging markets, particularly those in Asia. This discussion provides an even stronger motivation for assessing distributional effects of certain policies and policy responses to shocks.

\section{A Selection of Policies and Their Distributional Implications}

In this section, I provide a general overview of a range of macroeconomic policy choices and how they have distributional implications, either by themselves or because they constrain or influence other policy choices. This discussion is intended to be illustrative rather than exhaustive. ${ }^{5}$

\footnotetext{
${ }^{5}$ Goldberg and Pavcnik (2007) provide a nice survey and some evidence about the effects of globalization on inequality in developing economies. Woo et al. (2013) discuss empirical evidence on the distributional impact of fiscal policies.
} 


\subsection{Monetary policy}

A basic channel through which monetary policy affects aggregate demand but also affects net borrowers and net savers differentially is the interest rate channel. Higher returns on savings benefit savers but, if accompanied by higher cost of borrowing, can affect the borrowing costs, and hence consumption demand, of net borrowers. These two channels of course work in the same direction in terms of dampening aggregate demand, by reducing the consumption of both types of agents. ${ }^{6}$

There are many other channels through which monetary policy affects distribution in an economy. ${ }^{7}$ Coibion et al. (2012) note that the net effects of monetary policy on income inequality depend on the relative importance of different channels. If expansionary monetary policy raises profits more than wages, then households with claims to ownership of capital — typically wealthier households — will tend to benefit more. Higher inflation could also disproportionately hurt households that have limited access to financial markets and therefore hold more currency. On the other hand, as noted earlier, low interest rates could benefit borrowers and penalize savers. ${ }^{8}$

These and other channels imply that there is no definitive prediction from theory about how monetary policy affects income inequality. Coibion et al. (2012) conclude that, in the U.S., contractionary monetary policy increases inequality of labor earnings, income, and consumption. This is contrary to the perception that expansionary U.S. monetary policy in the post-crisis period has contributed to a widening of income inequality. In a recent paper, researchers at the Bank of England (2012) make the interesting argument

\footnotetext{
${ }^{6}$ That higher interest rates increase the savings and reduce the consumption of households that are net savers assumes, as is generally the case, that the intertemporal substitution effect of higher saving rates dominates the wealth effect of higher returns on savings. There is some evidence that, in China, the two effects offset each other, so the intertemporal effect does not dominate (see Chamon and Prasad, 2010).

${ }^{7}$ An earlier literature looking at this issue includes work by Grossman and Weiss (1983), Rotemberg (1984), and Williamson (2008).

${ }^{8}$ In work related to this point, Doepke and Schneider (2006) examine the redistributive effects of inflation in the U.S. They conclude that the main losers from inflation are rich, old households, who hold a large fraction of outstanding bonds. Young households with fixed-rate mortgage debt ate the main winners.
} 
that the Bank's asset purchases indeed hurt fixed-income investors by keeping interest rates low but that the effects on pensioners and pension funds have been counterbalanced by the boost to prices of other financial assets as well as the broader stimulative macroeconomic effects.

In a similar vein, Brunnermeier and Sannikov (2012) argue that, when an economy is subject to macroeconomic and financial shocks, liquidity and deflationary spirals generate endogenous risk and redistribute wealth in a manner that worsens inequality. They suggest that expansionary monetary reduces endogenous risk, stabilizes the economy, and stimulates growth, all of which helps to rebalance wealth after an adverse shock. In their model, monetary policy effectively functions like a social insurance scheme in an economy that is beset by financial frictions.

There are of course other channels through which monetary policy has redistributive effects. For instance, tight monetary policy can affect credit access of smaller firms, especially in an economy with collateral constraints that limit borrowing. ${ }^{9}$ Expansionary monetary policy that is sustained over long periods can also reduce the relative price of capital, which could raise the capital-labor ratio, reduce employment growth, and redistribute income from labor to capital. ${ }^{10}$ While theoretical models have been helpful in identifying the various channels through which monetary policy has redistributive effects, the sheer number of channels suggests that the net redistributive effect is specific to each economy and even to the specific type of monetary policy action undertaken by a central bank.

In emerging markets, there are more basic questions about whether the relevant transmission mechanism for monetary policy is through the credit channel or, especially

\footnotetext{
${ }^{9}$ Domac (1999) finds that, in Malaysia, monetary tightening affects small and medium-sized firms more than large firms.

${ }^{10}$ Karabarbounis and Neiman (2013) document the global decline of the labor share in national income and argue that this shift is the result of the decrease in the relative price of investment goods. They attribute this shift in relative prices to advances in information technology, but - at least for some of the advanced economies - monetary policy could be an equally important factor in explaining their results.
} 
in small open economies, through the exchange rate channel. ${ }^{11}$ Other channels through which monetary policy can influence aggregate demand are short-term and long-term interest rates; asset prices; and expectations. The broad conclusion from the country studies in BIS (2008) is that the interest rate channels have become more important over time in emerging markets. However, with rising financial market turbulence and increasing financial and trade openness of these economies, the recent monetary policy actions of many emerging market central banks suggest that the importance of the exchange rate channel may have been resuscitated to some extent. The discussion in the Section 3 will touch upon this issue, but there is still considerable work to be done in evaluating the distributional consequences of monetary policy choices conditional on the relevant transmission mechanism.

\subsection{Financial sector}

Financial repression often keeps interest rates artificially low, hurting those who rely on fixed income investments such as bank deposits or government securities, and who do not have easy access to other instruments for financial diversification. In China, for instance, the cap on bank deposit rates has kept real yields on bank deposits, adjusted for consumer price inflation, low or negative for most of the last decade and a half. This implies a significant net transfer from households whose primary source of income is labor income to enterprises and the owners of capital. ${ }^{12}$ Furthermore, as discussed in the previous subsection, financial repression also affects the relative price of capital and tends to favor capital-intensive rather than labor-intensive production.

In the wake of the financial crisis, there has been considerable interest in the relationship between financial deregulation and inequality. ${ }^{13}$ Korinek and Kreamer (2013) construct a

\footnotetext{
${ }^{11}$ See Hammond, Kanbur, and Prasad (2009) and Frankel (2010) for a further discussion of monetary policy frameworks in emerging market economies.

${ }^{12}$ See Prasad (2009) for a discussion of this issue and Lardy (2008) for estimates of the implied fiscal transfer from households resulting from the cap on deposit rates.

${ }^{13}$ Rajan's (2010) influential work discusses some of these issues in the context of the U.S. and other advanced economies. The discussion in the remainder of this section is in effect a formalization of some of the ideas proposed by Rajan.
} 
model in which financial deregulation allows the financial sector to benefit from risktaking. This increases the incidence of large losses, which are spread more broadly outside the financial sector and impose negative externalities on the real economy. The asymmetry between benefits and costs to the financial sector from risk taking implies that financial innovation shifts a greater share of the surplus to the financial sector at the expense of the rest of the economy.

Kumhof and Ranciere (2011) show that a shift in bargaining power over incomes in favor of investors and away from workers can lead to high leverage and crises. Investors purchase financial assets backed by loans to workers, allowing the latter to limit the drop in their consumption despite their loss of income. This generates high debt-to-income ratios among workers, who are relatively poor compared to investors, eventually resulting in a crisis. Thus, the model establishes a direct link between rising inequality and the probability of financial crises.

The relationship between financial deregulation and inequality is complex. In fact, policies ostensibly intended to promote financial inclusion by creating products that allow low-income and less-creditworthy households to obtain home financing through mortgages may have played a role in the crisis. The proliferation of such sub-prime mortgages in the U.S. was made possible by securitization of those mortgages that, in principle, allowed the risks to be spread. The reality proved to be different.

Financial deregulation that loosened borrowing constraints on low-income households and also resulted in more financing being available for sub-prime borrowers (through securitization of mortgage loans) created a dangerous combination. Political pressures to intervene in the functioning of mortgage markets before and after the crisis made some of these problems worse. A growing body of research has begun to illustrate these connections. Mian and Sufi (2009) use disaggregated data for the U.S. to show that zip codes with a disproportionately large share of subprime borrowers had a large growth in mortgage credit despite low income growth. The authors contend that these phenomena are correlated with the increase in securitization of subprime mortgages. Mian, Sufi, and 
Trebbi (2010) show that Congressional representatives whose constituents experience a sharp increase in mortgage defaults or who receive higher campaign contributions from the financial services industry tended to favor government intervention in the mortgage market.

\subsection{Exchange rate policies}

Exchange rate policies also have a redistributive element. Tightly managed exchange rates that limit currency appreciation in the short term can benefit producers (and, under some circumstances, also workers) in the tradable goods sector. In the presence of nominal rigidities, management of the nominal exchange rate can delay the adjustment of the real exchange rate in response to positive productivity shocks. Such a policy is less beneficial to the average household in the economy, which cannot benefit from cheaper imports, and to domestic agents that may have borrowed abroad in foreign currency loans. Moreover, poor households that mainly use cash for savings and other transactions would face a disproportionate burden if the real exchange rate adjustment eventually took place largely through higher domestic inflation. Of course, many of these effects may be opposite and symmetric if the exchange rate policy were to delay real exchange rate depreciation in response to adverse shocks to productivity or other factors.

Exchange rate management can also have broader consequences if it results in financial repression. Foreign exchange market intervention can become quite expensive for central banks as they cope with the costs of sterilizing that intervention. This often leads to financial repression that can take different guises. It can involve explicit directives to domestic banks to buy government debt, which has consequences for financial sector efficiency. In China, the ceiling on interest rates paid on bank deposits and caps on the quantity of bank lending have in the past encouraged commercial banks to buy large quantities of central bank bonds. This reduced the explicit cost of the central bank's sterilized intervention in foreign exchange markets, but at a significant cost to depositors and impeding the efficient functioning of the banking system. ${ }^{14}$

\footnotetext{
${ }^{14}$ See Prasad (2009) for a detailed discussion of this issue.
} 


\subsection{Capital controls}

Capital controls are increasingly seen as a useful prudential tool that can help promote financial stability in economies that are vulnerable to large and volatile capital flows. However, controls have important distributional consequences in terms of access to finance and to risk-sharing opportunities.

There is some evidence that controls disproportionately affect small and medium-sized firms, as larger firms generally find it easier to get around controls and raise foreign financing. ${ }^{15}$ Larger firms also tend to have better political connections, giving them preferential access to controlled inflows. This leads to reduced financing for small firms and could have particularly deleterious impacts on service sector firms, which tend to be smaller, more labor intensive, and typically better at generating employment than capitalintensive manufacturing firms. Rather than delivering the indirect, collateral benefits of financial openness, capital controls sometimes end up perpetuating domestic inefficiencies and fostering corruption. ${ }^{16}$

Capital controls can also have a greater impact on poor households compared to wealthier ones. The latter typically have access to more channels that help them evade the controls and bring money into or out of a country. One manifestation of the aggregate consequence of this disparity is in terms of risk sharing. Limited capital account opening can have perverse consequences on overall national risk sharing. For countries at low or intermediate levels of financial openness, a simple measure of risk sharing - the ratio of aggregate consumption volatility to aggregate income volatility actually increases with rising financial openness. ${ }^{17}$ This is exactly the opposite of the ostensible risk-sharing benefits of opening up to financial flows.

\footnotetext{
${ }^{15}$ See Forbes (2007). Klein (2012) has a broader discussion of the impact and effectiveness of different types of capital controls.

${ }^{16}$ For a discussion of the potential collateral benefits of financial openness, see Kose et al. (2009).

${ }^{17}$ See Kose, Prasad, and Terrones (2009).
} 
One of the explanations that has been suggested for this result is that, in a closed economy, different types of households share household-specific risk amongst themselves but are unable to insure against aggregate (country-level) shocks (Levchenko, 2005). Opening up the capital account should give all types of households the ability to diversify their portfolios internationally and achieve better risk sharing outcomes. However, because of market segmentation, only a subset of households in the economytypically the more well-off-have access to these investment opportunities. Consequently, those households stop sharing risk with other domestic households and this could in fact diminish the amount of overall insurance against idiosyncratic shocks. Thus, under certain choices of key model parameters, the ratio of aggregate consumption volatility to income volatility could in fact rise as a consequence of financial opening.

In a world with undisciplined and volatile capital flows, financial regulatory policies that have characteristics in common with capital controls might well play a useful role in ensuring financial stability. But the above discussion suggests that it is imperative for policymakers to pay careful attention to the various potential distributional effects of such policies.

\section{Two Examples}

The previous section indicated that distributional effects can be important across a broad range of policies and deserve greater attention in formal economic models. In this section, I discuss two examples, both drawn from my recent work, that attempt to analyze distributional consequences of certain policy choices related to monetary frameworks. The first example shows how modeling the existence of financial frictions - with only a subset of households in the economy having access to financial markets that allow for intertemporal consumption smoothing - can overturn a classical result about the welfareimproving choice of price index for targeting inflation. The second example illustrates that distributional effects are not only important in and of themselves but also because policy responses to try and counter those effects can in turn have aggregate welfare consequences. 


\subsection{Core vs. Headline Inflation Targeting Under Incomplete Markets}

The global financial crisis has reinvigorated the debate about the appropriate objectives for monetary policy. A consensus appears to be building that the inflation targeting (IT) framework has delivered price stability and should be retained but that central banks should use prudential regulation and other policy tools to counteract asset price bubbles. ${ }^{18}$ Whether or not IT is the chosen framework, central banks around the world view low and stable inflation as a primary, if not dominant, objective of monetary policy.

What is the right price index that should be the focus of the inflation objective? This is a central operational issue in implementing not just IT but any version of monetary policy. In the existing literature, the choice of price index has been guided by the idea that inflation is a monetary phenomenon. It has been suggested that core inflation (excluding food, energy and other volatile components from headline CPI) is the most appropriate measure of inflation. ${ }^{19}$ The logic is that fluctuations in food and energy prices represent supply shocks and are non-monetary in nature. Since these shocks are transitory and volatile and do not reflect changes in the underlying rate of inflation, they should not be a part of the inflation targeting price index..$^{20}$

This logic is supported by previous research based on models with price and/or wage stickiness, which show that targeting core inflation maximizes welfare. Existing models have looked at complete market settings where price stickiness is the only source of distortions (besides monopoly power). Infrequent price adjustments cause mark-ups to fluctuate and also distort relative prices. In order to restore the flexible price equilibrium, central banks should try to minimize these fluctuations by targeting sticky prices. ${ }^{21}$ For instance, using a variant of a New Keynesian model, Aoki (2001) has shown that under complete markets targeting inflation in the sticky price sector leads to welfare

\footnotetext{
${ }^{18}$ See, for instance, Eichengreen et al. (2011). Clarida, Gali, and Gertler $(1998,1999)$ summarize the earlier orthodoxy and discuss alternative perspectives. Mohanty and Klau (2004) discuss some issues related to monetary policy rules for emerging market economies.

${ }^{19}$ See Wynne (1999).

${ }^{20}$ See Mishkin $(2007,2008)$.

${ }^{21}$ See Goodfriend and King $(1997,2001)$.
} 
maximization and macroeconomic stability. Targeting core inflation is equivalent to stabilizing the aggregate output gap as output and inflation move in the same direction under complete markets.

These results from the prior literature rely on the assumption that markets are complete (allowing households to fully insure against idiosyncratic risks). The central bank then only needs to tackle the distortions created by price stickiness. However, there is compelling evidence that a substantial fraction of agents even in advanced economies are unable to smooth their consumption in a manner consistent with the permanent income hypothesis. $^{22}$ This leaves open the issue of analytically determining the appropriate price index for markets with financial frictions in general and emerging markets in particular. ${ }^{23}$

In a recent paper (Anand and Prasad, 2012), I develop a model to evaluate the welfare implications of targeting different price indices in an incomplete markets setting that is particularly relevant for emerging markets. The objective is not to define optimal policy rules but, rather, to evaluate welfare outcomes of different policy rules using alternative measures of inflation. This model is used to provide welfare comparisons of the practical choice that most central banks face-targeting core or headline inflation, along with some variants of those rules.

Financial frictions that result in consumers being credit-constrained have not received much attention in models of inflation targeting. To examine the significance of such frictions, which are particularly relevant for emerging markets, the model incorporates heterogeneous agents. It is assumed that a fraction of consumers cannot smooth their

\footnotetext{
${ }^{22}$ Campbell and Mankiw $(1989,1990)$ estimate that in the U.S. nearly 50 percent of income accrues to consumers who do not smooth their consumption. For more evidence on the proportion of credit-constrained consumers in the U.S., see the discussion in Anand and Prasad (2012).

${ }^{23}$ This discussion abstracts from other issues relevant to designing optimal inflation targeting regimes - such as the choice of a point target versus a band, the horizon over which inflation should be targeted, appropriate level of the target, and the implications of uncertainty about the perceived target.
} 
consumption — that is, they simply consume their current labor income. ${ }^{24}$ When markets are not complete and agents differ in their ability to smooth consumption, their welfare depends on the nature of idiosyncratic shocks. Thus, this model enables the analysis of changes in the welfare distribution under alternative inflation targeting rules.

When markets are complete, the income distribution following a sector-specific shock does not matter for the choice of consumption and, hence, welfare. However, under incomplete markets, household income, which is influenced by the nature of shocks and the price elasticity of the demand for goods, matters for consumption choices. Through its impact on household income and expenditure, the price elasticity of the demand for food, which is low in emerging market economies, affects welfare outcomes from core and headline inflation targeting under incomplete markets. For instance, a negative productivity shock to a good with a low price elasticity of demand could increase the income of net sellers of that good and raise the expenditure of net buyers of that good.

The model also incorporates other important features relevant to emerging markets. The share of food in total household expenditures is higher in emerging markets, constituting 40-50 percent of household expenditures compared to 10-15 percent in advanced economies. Low price and income elasticities of food expenditures as well as low income levels make the welfare of agents in emerging markets more sensitive to fluctuations in food prices. These features imply that agents factor in food price inflation while bargaining over wages, thus affecting broader inflation expectations. Thus, in emerging markets even inflation expectation targeting central banks must take into account food price inflation. ${ }^{25}$

One key result, based on a version of the model calibrated to match important properties of emerging market data, is that in the presence of financial frictions targeting headline

\footnotetext{
${ }^{24}$ This friction is similar to that in Gali, Lopez-Salido and Valles (2004). Blanchard and Gali (2010) evaluate monetary policy rules in the presence of labor market frictions, real wage rigidities, and staggered price setting.

${ }^{25}$ Walsh (2011) documents the high pass-through from food price inflation to nonfood inflation in middle- and low-income countries.
} 
CPI inflation improves aggregate welfare relative to targeting core inflation (i.e., inflation in the sticky price sector). The intuition is as follows. Lack of access to financial markets makes the demand of credit-constrained consumers insensitive to fluctuations in interest rates. ${ }^{26}$ These consumers' demand depends only on real wages, establishing a link between aggregate demand and real wages. Thus, in the presence of financial frictions, the relative price of the good produced in the flexible price sector not only affects aggregate supply but, through its effects on real wages, also influences aggregate demand.

If the central bank ignores fluctuations in the flexible price sector, aggregate demand may in fact move in the opposite direction to what is intended by the monetary policy intervention. To have the desired effect on aggregate demand, the central bank has to target a price index that would dampen the response of credit-constrained consumers. In the model's specific setting, this means that the central bank should target headline inflation. The results have special significance for central banks in emerging markets. Given the prevalence of financial frictions in these economies, the conventional view that targeting core CPI inflation can best stabilize inflation and output therefore needs to be re-examined.

This result differs from that obtained in the prior literature based on complete markets settings. For instance, in Aoki's (2001) model, relative prices of the flexible price sector only appear as a shift parameter of inflation in the sticky price sector. Under incomplete markets, by contrast, the central bank has to take account of price fluctuations in the flexible price sector in order to manage aggregate demand. Financial frictions break the comovement of inflation and output (as inflation and output may now move in opposite directions). Stabilizing core inflation no longer suffices to stabilize the output gap. Thus, in the presence of financial frictions, targeting headline inflation is a better policy choice.

\footnotetext{
${ }^{26}$ In the baseline version of the model, all of the households in the flexible price sector are credit constrained. One can think of these as rural households producing agricultural commodities. Basu and Srivastava (2005) document that 80 percent of individuals in India's agricultural sector have no access to formal finance.
} 
To sum up, in the presence of credit-constrained consumers, targeting core inflation is no longer welfare maximizing. Also, stabilizing inflation is not sufficient to stabilize output when markets are not complete. Under these conditions, flexible headline inflation targeting - which involves targeting headline inflation and putting some weight on the output gap-improves welfare relative to the practical alternatives that we consider. ${ }^{27}$

\subsection{Inflation Targeting vs. Nominal Exchange Rate Targeting}

In ongoing research, I am developing a class of models to study other distributional consequences of monetary policy in emerging markets. These models have more general applicability for all economies with financial market imperfections, which could include advanced economies, although that is not the immediate focus of the research. In a recent paper (Prasad and Zhang, 2013), I analyze a specific contemporary policy issue that central bankers in middle-income emerging market economies face, one that has been particularly relevant for Asian emerging market economies. This relates to the choice between accepting real exchange rate appreciation through nominal appreciation or higher domestic inflation. The analysis aims to examine not just the aggregate implications but also the distributional consequences of this particular policy choice.

With higher productivity growth relative to their advanced economy trading partners, emerging market economies are likely to experience trend real exchange rate appreciation. Many of these economies have on occasion also faced bouts of sharp short-run appreciation pressures due to the unconventional monetary policy actions of advanced economies. Central bankers in these economies, fearful of exchange rate overshooting in the short run and the effects this could have on the competitiveness of their exports, have attempted to limit nominal exchange rate appreciation. Some countries like China tightly manage the nominal exchange rate while many emerging markets, such as India and

\footnotetext{
${ }^{27}$ The specific alternative monetary policy rules we consider are strict core inflation targeting, flexible core inflation targeting, and strict headline inflation targeting. The "strict" inflation targeting rules put zero weight on the output gap. All of the rules whose welfare effects we examine include an interest rate smoothing parameter. Catão and Chang (2013) evaluate alternative monetary rules, including PPI targeting and export price targeting, for economies with different structures of imports and exports.
} 
others in Asia, adopt a policy of leaning against the wind to limit what they view as excessive exchange rate volatility but otherwise not actively resisting currency appreciation (or depreciation).

In a world with flexible prices and no other rigidities, managing the nominal exchange rate will simply shift the channel of real exchange rate appreciation to higher domestic inflation. ${ }^{28}$ However, with inertial price dynamics, real exchange rate appreciation can be limited at least in the short run through nominal exchange rate management. Such exchange rate management is likely to continue in practice given the absence of growth momentum in both advanced and emerging market economies and the prospect of continued unconventional monetary policy actions by advanced economy central banks. In view of these circumstances, central banks in emerging markets will face strong domestic pressures to intervene more heavily in foreign exchange markets to forestall rapid currency appreciation.

This policy choice has significant distributional consequences, particularly on account of financial frictions and household heterogeneity in emerging market economies. In an export-oriented economy in which the interests of the exporting sector are given prominence for political economy reasons, a policy attempting to keep the currency undervalued can help maintain the competitiveness of the traded goods sector and give it more time to adjust to eventual real exchange rate appreciation. However, if this policy raises domestic inflation (through unsterilized foreign exchange market intervention), it can have negative consequences for other sectors of the economy and could even reduce aggregate welfare. The benefit of higher productivity, which leads to the pressures for real appreciation, would not translate into lower prices for traded goods that would improve the purchasing power and consumption possibilities for the average household. Productive firms in the traded goods sector are also more likely to be owned by households with higher levels of wealth, which further exacerbates these distributional effects. Hence, it is important to assess the magnitude of both the aggregate and

\footnotetext{
${ }^{28}$ In most settings, the situation is symmetric in terms of pressures for real exchange rate depreciation leading to disinflation if the nominal exchange rate is tightly managed - so long as the price adjustment process is symmetric.
} 
distributional consequences of monetary policy choices.

Preliminary results from the model indicate that, relative to an inflation targeting framework with flexible exchange rates, a nominal exchange rate targeting rule can have large distributional effects. Even with labor being perfectly mobile between the traded and nontraded goods sectors, the result arises due to disparities in ownership of capital, with higher capital intensity in the traded goods sector. If households in the nontraded goods sector (whose earnings depend entirely on labor income rather than capital income) lack access to financial markets for sharing income risk, then the distributional consequences can be significant. More importantly, the aggregate consequences of such a policy can in fact be negative if foreign exchange market intervention sparks higher inflation, which in turn adversely affects households with limited financial access.

\section{Implications for Policy and Research}

Even if one accepts that the distributional consequences of macroeconomic policies are worth more attention, there remains the question of what dimension of heterogeneity is important when evaluating welfare consequences of different policies. Heterogeneity in initial wealth distributions and the distribution of productivity across households have been shown to matter in evaluating policy choices. Wealth distributions or heterogeneity in terms of skill levels can matter for the propagation and persistence of aggregate shocks. There is a long literature on poverty traps, which details how transitory shocks such as adverse weather shocks or unemployment spells can have persistent effects at the household level. Similarly, skill-biased technological shocks can have differential and highly persistent effects on the wages and employment probabilities of workers with different skill levels and also have differential effects across sectors. ${ }^{29}$

In the context of macroeconomic stabilization policies, the two examples discussed in the previous section suggest one aspect of heterogeneity that matters greatly for both distributional and aggregate consequences. For many macroeconomic policies, especially

${ }^{29}$ See, for instance, Krusell et al. (2003). 
those related to monetary or financial sector policies, access to financial markets (sometimes referred to as financial inclusion) may be one of the crucial dimensions of heterogeneity.

The term financial access is broadly defined to include a variety of concepts. ${ }^{30}$ The first element is the existence of a broad set of financial markets and institutions, while the second is the more direct element of access to the formal financial system, such as through bank accounts. Conditional on the existence of a broad set of financial markets, the level of access tends to be correlated with variables such as initial wealth or average income levels, or even variables such as education that in turn are indicators of productivity. But this correlation is one that can be influenced by policies specifically targeted to improving financial access.

From a modeling perspective, the main aspect of heterogeneity is the ability to use financial markets to insure against household-specific or sector-specific shocks. Heterogeneity in this dimension is the crucial one that delineates different types of households in terms of how they are able to deal with macroeconomic shocks and the policy responses to them. The two examples discussed in the previous section have emphasized this element of heterogeneity.

One question is whether stripped-down models that incorporate heterogeneous agents, such as those discussed in the previous section, in fact provide useful guidance to policymakers or if the models need to be brought closer to reality by inserting additional features. A possible extension of the model looking at different measures of price indexes (Section 3.1), for instance, would be to include money explicitly. While this would provide a saving mechanism for hand-to-mouth consumers, it would in fact strengthen the case for headline inflation targeting to preserve the value of monetary savings. Another extension would be to include physical capital in the same model. This would highlight a practical dilemma that emerging market central banks are grappling with in

\footnotetext{
${ }^{30}$ See Čihák et al. (2012). The IMF's Financial Access Survey (fas.imf.org) provides crosscountry data on a useful set of indicators of financial inclusion. For a discussion of practical difficulties and pitfalls in expanding financial access, see World Bank (2008).
} 
pursuit of their objective of price stability (low inflation). For instance, India's central bank, the Reserve Bank of India, has been forced to repeatedly raise policy rates in recent years to deal with surging food price inflation even though the rate hikes hurt industrial activity in an economy already facing weak growth prospects. Central banks in many other emerging markets face similar policy challenges.

Although they are highly stylized, such models with financial frictions can still provide useful insights into the difficult dilemmas that policymakers face and factors they need to consider when making policy choices. In emerging market and low-income economies, the classical result, which implies that central banks should ignore food price inflation when making monetary policy decisions, is not politically tenable. Raising interest rates in response to a transitory negative shock to agricultural sector productivity that raises food prices might seem counter-intuitive. But the results outlined in the previous section suggest that such a policy could in fact be welfare improving in a setting with incomplete financial markets and with additional features of emerging markets such as the high level of food expenditure in household consumption expenditure.

\section{Some Reflections on the Policy Mix}

To this point, I have focused on the distributional effects of specific policies. How different policies are combined to achieve desired outcomes can also have distributional consequences. For instance, in the U.S., short-term fiscal austerity measures in addition to unconventional monetary policies may have contributed to a weakening of the social safety net and a widening of income inequality in the aftermath of the financial crisis and the deep recession associated with it. Whether this plausible proposition is true requires more careful analysis of income but also social transfers through various safety net mechanisms. $^{31}$

\footnotetext{
${ }^{31}$ Piketty and Saez (2013b) present updated data on the rising inequality of income in the U.S. By contrast, Armour, Burkhauser, and Larrimore (2013) find much more modest increases in inequality based on a different treatment of capital income.
} 
For emerging market economies, particularly those in Asia, the broader question of how different policies are used to buffer the effects of capital flow volatility has become a pressing policy issue. In this concluding section, I provide some broader reflections on why the analysis of monetary policy has become particularly important for these economies.

\subsection{Monetary Policy as First and Last Line of Defense}

One of the key challenges that emerging market central bankers face as their economies become more open to capital flows is managing the volatility of those flows. Capital flows remain highly volatile and procyclical, and often accentuate domestic policy and institutional weaknesses in these economies. Before designing solutions for these problems, however, it is important to think about the sources of failures relative to the benchmark of the ideal pattern of capital flows in a frictionless world with wellfunctioning financial markets. ${ }^{32}$ Conceptually, one can think about three related sets of problems - market failures, policy failures, and institutional failures. The distinction among these three types of failures is not as clear as suggested below, but the coarse typology still has its uses.

Market failures are in some sense the easiest for academic economists, at least, to analyze. These failures can occur, for instance, when there is herding behavior because of information asymmetries in markets or because of the structure of incentives for investment managers in financial institutions. It is relatively easy to determine, at least

\footnotetext{
${ }^{32}$ See Prasad $(2013,2014)$. In brief, capital flows in a first-best world (from the perspective of emerging market economies) would be characterized by the following features. First, relatively stable capital flows, especially in the form of foreign direct investment, that convey important collateral benefits such as positive spillovers of technology, managerial expertise, and corporate governance practices (see Kose et al, 2009). Second, capital flows driven mainly by macroeconomic fundamentals, such as output growth, productivity, and interest rates. Third, capital flows that cushion domestic business cycle conditions and facilitate international risk sharing, which implies countercyclical net inflows. Fourth, capital flows being mediated through relatively well regulated domestic and international financial markets. And fifth, from the perspective of emerging markets, sound and stable macro policies in the advanced economies that do not by themselves become sources of capital flow volatility.
} 
broadly, what steps need to be taken to reduce certain market failures and their impact. Of course, it may still be difficult to implement those changes given the enormous resistance from those who have an interest in maintaining the status quo and not changing regulatory regimes.

Next comes the issue of policy failures. Undisciplined macroeconomic policies and inconsistent or ineffectual financial regulatory policies can heighten the risks associated with volatile capital flows. In this case as well, the solutions are not difficult to discern, even if they are not always easy to implement. There are specific types of policies, such as financial regulatory policies, that could in fact direct capital flows to productive uses once they enter an economy. Macroprudential requirements are essentially a device for trying to direct capital inflows into the most productive channels and helping domestic investors attain the benefits of risk sharing through capital outflows that help them diversify their portfolios.

Here again, it is not straightforward but still feasible to think about specific policies that improve the benefit-cost tradeoff from capital flows. The policy challenge is not just about better financial market regulation but also about improving the functioning of financial markets (both by encouraging financial market development and ensuring adequate regulatory capacity) and managing fiscal policy more prudently.

The third source of the discrepancies between theory and reality is the most complicated one. I label this third category as institutional failures, which in turn have two dimensions--domestic and international.

First, on the domestic front, the critical issue is that of thinking about the suitable balance of macroeconomic policies. Most central bankers now face multiple, and indeed, expanding mandates. This is a failure at the institutional level within countries. The problem is that monetary policy has become the main policy tool to deal with macroeconomic stabilization as well as to ensure financial stability and promote growth. In the advanced economies, in particular, a great deal needs to be done to achieve long- 
term fiscal retrenchment and promote structural reforms, but instead policymakers have been relying on the relatively easy crutch of monetary policies both to prevent financial meltdown and support growth.

The same is true of some emerging market economies, where central banks have had to take on multiple objectives - maintaining low inflation, supporting growth, keeping the currency's external value reasonably stable, and ensuring financial stability. In the absence of support from other policies, central banks have had to wage a lone battle to manage this difficult and sometimes conflicting set of objectives. In India, for instance, the Reserve Bank of India has been forced to contain inflation that has been driven to a significant extent by supply-side factors. Fiscal policies, including the level of the deficit and the composition of fiscal expenditures, and supply-side policies (including the labor laws and regulatory regimes in different sectors) have not been supportive of growth, adding to the burden on the central bank to manage a difficult balancing act.

In this situation, monetary policy is hemmed in by the configuration of other policies. Institutional changes that promote more disciplined fiscal and structural policies, and thus alter the policy mix, can facilitate the central bank's focus on a more limited set of policy objectives.

The second aspect is the institutional framework at the international level. The difficult reality is that, with increasing financial integration, there are going to be ever-larger spillovers of policy measures from the advanced economies to the emerging markets, and indeed the other way around as well. There is at present no good governance mechanism in place to cope with these spillovers. Asking major central banks to take on an additional mandate in terms of looking at the spillover effects of their policies seems logical but further complicates an already difficult situation as the domestic mandates for these institutions multiply.

But ultimately there is little choice other than to confront these issues, both in terms of thinking more formally about spillover effects and also about the governance structure of 
international institutions, whose legitimacy has to be rebuilt if they are to be effective at helping solve collective action problems related to macroeconomic policies.

The lack of effective global governance has major implications for capital flows. ${ }^{33}$ Emerging markets feel that they have to accumulate more foreign exchange reserves, which forces them to buy advanced economy debt as safe assets that provide a layer of protection from volatile capital flows. The reality of the financial crisis in particular, and indeed even before, is that the demand for safe assets for emerging markets has been rising. In the aftermath of the financial crisis, conventional norms of reserve adequacy are no longer tenable. There appears to be a sense among policymakers in these countries that having more reserves is better despite the opportunity costs those reserves entail.

At the same time that demand for financial safe assets is rising, the availability of such assets has declined considerably. It is now clear that not all eurozone bonds are the same in terms of their perceived default risk and other characteristics. Moreover, countries like Japan and Switzerland are in fact demanding safe assets right now rather than supplying them. The private sector demand for safe assets has gone up, perhaps for the right reasons, but it is coming on top of rising sovereign demand for such assets. A small group of advanced economies has become the major providers of safe assets, the U.S., of course, becoming the dominant provider. This is not a tenable situation, where the institutional set-up in the international arena leaves emerging markets feeling that they don't have any recourse in terms of safety nets other than self-insurance through reserve accumulation. This situation is likely to perpetuate imbalances in global financial flows if emerging market economies remain net exporters of capital to advanced economies.

Solutions such as capital controls can create a buffer in the short term but ultimately, it will be necessary to get a firmer grasp on the underlying mix among the three types of failures discussed above and not try to use one set of policies based on a misdiagnosis of the underlying problem. When the relevant failures are really domestic policy failures, they need to be confronted as such rather than viewing the problem as being an external

${ }^{33}$ See Prasad (2014, Chapter 5) for a discussion. 
one that needs to be dealt with through a mechanism like capital controls. Ultimately, unless the domestic and international institutional weaknesses are fixed, both the domestic policy measures as well as measures to improve the functioning of financial markets, while necessary, might end up being futile.

To summarize, emerging market policymakers are being confronted by complex challenges related to both their domestic and global economic landscapes. When analyzing the configuration of domestic policies and the suitable mix among them to cope with both short-term and long-term challenges, it is important to consider distributional as well as aggregate consequences. For monetary policy, this means a more careful assessment of a broader set of consequences - in addition to growth, inflation, and financial stability — of specific monetary policy tools and policy actions. It would be premature (and possibly even counterproductive) to make distributional criteria an explicit objective of monetary policy but, in tandem with the effects of other policies, this dimension of economic outcomes should be given consideration in formulating monetary policy actions and determining its mix with other macro stabilization policies. Academic economists face an equally daunting challenge in developing models that can provide guidance to policymakers on these issues. 


\section{References}

Anand, Rahul, and Eswar Prasad, 2012, "Core vs. Headline Inflation Targeting in Models with Incomplete Markets," Manuscript, Cornell University, Revised version of NBER Working Paper No. 16290.

Aoki, Kosuke, 2001, "Optimal Monetary Policy Responses to Relative Price Changes," Journal of Monetary Economics, Vol. 48, No. 1, pp. 55-80.

Armour, Philip, Richard V. Burkhauser, and Jeff Larrimore. 2013, "Deconstructing Income and Income Inequality Measures: A Crosswalk from Market Income to Comprehensive Income," American Economic Review, Vol. 103, No. 3, pp. 173 77.

Baldacci, Emanuele, Luiz de Mello, and Gabriela Inchauste, 2002, "Financial Crises, Poverty, and Income Distribution," IMF Working Paper 02/4.

Bank of England, 2012, “The Distributional Effects of Asset Purchases," Research Paper.

Basu, Priya, and Pradeep Srivastava, 2005, "Scaling-up Microfinance for India's Rural Poor," World Bank Policy Research Working Paper No. 3646.

BIS, 2008, "Transmission Mechanisms for Monetary Policy in Emerging Market Economies,” BIS Papers No. 35. Basel, Switzerland: Bank for International Settlements.

Blanchard, Olivier, and Jordi Gali, 2010, "Labor Market Frictions and Monetary Policy: A New Keynesian Model with Unemployment," American Economic Journal: Macroeconomics, Vol. 2, No. 2, pp. 1-30.

Brunnermeier, Markus K., and Yuliy Sannikov, 2013, "Redistributive Monetary Policy," Proceedings of the 2012 Jackson Hole Symposium, Federal Reserve Bank of Kansas City.

Campbell, John Y., and N. Gregory Mankiw, 1989, "Consumption, Income, and Interest Rates: Reinterpreting the Time Series Evidence," NBER Macroeconomics Annual, Vol. 4, eds. Olivier Jean Blanchard and Stanley Fischer (Cambridge, MA: MIT Press), pp. 185-216.

— 1990, "Permanent Income, Current Income, and Consumption," Journal of Business and Economic Statistics, Vol. 8, No. 3, pp. 265-279.

Catão, Luis, and Roberto Chang, 2013, "Monetary Rules for Commodity Traders," IMF Economic Review, Vol. 61, No. 1, pp. 52-91.

Chamon, Marcos, and Eswar S. Prasad, 2010, "Why Are Saving Rates of Urban Households in China Rising?" American Economic Journal: Macroeconomics, Vol. 2, No. 1, pp. 93-130. 
Čihák, Martin, Aslı Demirgüç-Kunt, Erik Feyen, and Ross Levine. 2012, "Benchmarking Financial Systems around the World," Policy Research Working Paper 6175, (Washington, DC, World Bank).

Clarida, Richard, Jordi Gali, and Mark Gertler, 1998, "Monetary Policy Rules in Practice: Some International Evidence," European Economic Review, Vol. 42, Issue 6, pp. 1033-67.

Clarida, Richard, Jordi Gali, and Mark Gertler, 1999, "The Science of Monetary Policy: A New Keynesian Perspective," Journal of Economic Literature, Vol. 37, No. 4, pp. 1661-1707.

Coibion, Olivier, Yuriy Gorodnichenko, Lorenz Keung, and John Silvia, 2012, "Innocent Bystanders? Monetary Policy and Inequality in the U.S.," NBER Working Paper No. 18170 (Cambridge, Massachusetts, National Bureau of Economic Research).

Committee on International Economic Policy and Reform, "Rethinking Central Banking," (Washington, DC, Brookings Institution).

Dao, Mai, and Prakash Loungani, 2010, "The Human Cost of Recessions: Assessing It, Reducing It," IMF Staff Position Note, SPN/10/17 (Washington, International Monetary Fund).

Demirguc-Kunt, Asli, and Leora Klapper, 2012, "Measuring Financial Inclusion: The Global Findex Database,” World Bank Policy Research Working Paper No. 6025.

Doepke, Matthias, and Martin Schneider, 2006, "Inflation and the Redistribution of Nominal Wealth," Journal of Political Economy, Vol. 114, No. 6, pp. 1069-1097.

Domac, Ilker, 1999, "The Distributional Consequences of Monetary Policy: Evidence from Malaysia,” World Bank Policy Research Paper.

Eichengreen, Barry, and others 2011, "Rethinking Central Banking," Report of the Committee on International Economic Policy and Reform (Washington, DC, Brookings Institution).

Forbes, Kristin, 2007, “One Cost of the Chilean Capital Controls: Increased Financial Constraints for Smaller Traded Firms," Journal of International Economics, Vol.71, No. 2, pp. 294-323.

Frankel, Jeffery A., 2010, "Monetary Policy in Emerging Markets: A Survey," NBER Working Paper No. 16125.

Gali, Jordi, Lopez-Salido, David J., and Javier Valles, 2004, "Rule-of-Thumb Consumers and The Design Of Interest Rate Rules," Journal of Money, Credit and Banking, Vol. 36, No. 4, pp. 739-763. 
Goldberg, Pinelopi K., and Nina Pavcnik, 2007, "Distributional Effects of Globalization in Developing Countries," Journal of Economic Literature, Vol. 45, No. 1, pp. 39-82.

Goodfriend, Marvin, and Robert King, 1997, "The New Neoclassical Synthesis and the Role of Monetary Policy," in NBER Macroeconomics Annual, Vol. 12, ed. by Ben S. Bernanke and Julio J. Rotemberg (Cambridge, Massachusetts, MIT Press), pp. 231-83.

Goodfriend, Marvin, and Robert King, 2001, "The Case for Price Stability," in The First ECB Central Banking Conference: Why Price Stability? ed. by Alicia G. Herrero, Vitor Gaspar, Lex Hoogduin, Julian Morgan, and Bernhard Winkler (Frankfurt, Germany, European Central Bank), pp. 53-94.

Grossman, Sanford, and Laurence Weiss, 1983, "A Transactions-Based Model of the Monetary Transmission Mechanism," American Economic Review, Vol. 73, No. 5, pp. 871-880.

Hammond, Gill, Ravi Kanbur, and Eswar S. Prasad, editors, 2009, Monetary Policy Frameworks for Emerging Markets, Cheltenham, U.K.: Edward Elgar.

Karabarbounis, Loukas, and Brent Neiman, 2013, "The Global Decline of the Labor Share," Manuscript, University of Chicago.

Klein, Michael, 2012, “Capital Controls: Gates versus Walls,” Brookings Papers on Economic Activity, Fall 2012 (Washington, DC, Brookings Institution).

Korinek, Anton, and Jonathan Kreamer, 2013, “The Redistributive Effects of Financial Deregulation,” Manuscript, Johns Hopkins University.

Kose, M. Ayhan, Eswar S. Prasad, Kenneth Rogoff, and Shang-Jin Wei, 2009, "Financial Globalization: A Reappraisal,” IMF Staff Papers, Vol. 56, No. 1, pp. 8-62.

Kose, M. Ayhan, Eswar S. Prasad, and Marco E. Terrones, 2009, "Does Financial Globalization Promote Risk Sharing?” Journal of Development Economics, Vol. 89, No. 2, pp. 258-70.

Kose, M. Ayhan, and Eswar S. Prasad, 2010, Emerging Markets: Resilience and Growth Amid Global Turmoil (Washington, DC, Brookings Institution Press).

Krusell, Per, Lee E. Ohanian, Jose-Victor Rios-Rull, and Giovanni L. Violante, 2003, "Capital-Skill Complementarity and Inequality: A Macroeconomic Analysis," Econometrica, Vol. 68, No. 5, pp. 1029-1053.

Kumhof, Michael, and Romain Ranciere, 2011, "Inequality, Leverage, and Crises," Manuscript (Washington, DC: International Monetary Fund). 
Lardy, Nicholas R. 2008. "Financial Repression in China," Policy Brief 08-8, (Washington, DC: Peterson Institute for International Economics).

Levchenko, Andrei, 2005, "Financial Liberalization and Consumption Volatility in Developing Countries," IMF Staff Papers, Vol. 52, No. 2, pp. 237-59.

Mian, Atif R., and Amir Sufi, 2009, "The Consequences of Mortgage Credit Expansion: Evidence from the U.S. Mortgage Default Crisis," Quarterly Journal of Economics, Vol. 124, No. 4.

Mian, Atif R., Amir Sufi, and Francesco Trebbi, 2010, "The Political Economy of the U.S. Mortgage Default Crisis," Manuscript, American Economic Review, Vol. 100, No. 5.

Mishkin, Frederic S., 2007, "Inflation Dynamics," Speech delivered at the Annual Macro Conference, Federal Reserve Bank of San Francisco, San Francisco, March 23, www.federalreserve.gov/newsevents.

, 2008, "Does Stabilizing Inflation Contribute to Stabilizing Economic Activity," Speech delivered at East Carolina University's Beta Gamma Sigma Distinguished Lecture Series, Greenville, North Carolina, February 25.

Mohanty, Madhusudan S., and Marc Klau, 2004, "Monetary Policy Rules in Emerging Market Economies: Issues and Evidence," BIS Working Paper No. 149 (Basel, Switzerland, Bank for International Settlements).

Piketty, Thomas and Emmanuel Saez, 2013a, "Top Incomes and the Great Recession: Recent Evolutions and Policy Implications," IMF Economic Review, Vol. 61, No.3, pp. 456-78.

Piketty, Thomas, and Emmanuel Saez, 2013b, Updated version of "Income Inequality in the United States, 1913-1998," Quarterly Journal of Economics, 2003, Vol. 118, No. 1, pp. 1-39.

Prasad, Eswar S., 2009, “Is China’s Growth Miracle Built to Last?” China Economic Review, Vol. 20, pp. 103-23.

__ 2013, "Managing Capital Flow Volatility," Address to the BIS-Bank of Russia Seminar for G-20 Central Bank Governors, July 2013. Forthcoming in BIS Papers.

— 2014, The Dollar Trap: How the Dollar Tightened Its Grip on Global Finance, Princeton, NJ: Princeton University Press.

Prasad, Eswar S., and Boyang Zhang, 2013, "Distributional Consequences of Alternative Monetary Policy Frameworks in Emerging Market Economies," Manuscript, Cornell University. 
Rajan, Raghuram, 2010, Fault Lines (Princeton, NJ, Princeton University Press).

Rotemberg, Julio J., 1984, “A Monetary Equilibrium Model with Transactions Costs," Journal of Political Economy, Vol. 92, No. 1, pp. 40-58.

Svensson, Lars E. O., 2011, "Monetary Policy after the Crisis," in Asia's Role in the Post-Crisis Global Economy, ed. by Reuven Glick and Mark M. Spiegel (San Francisco: Federal Reserve Bank of San Francisco).

Van Dijk, Mathijs A., 2013, "The Social Costs of Financial Crises,” Working Paper, Erasmus University.

Walsh, James, P., 2010, “Food Prices and Inflation,” Manuscript, IMF.

Williamson, Stephen D., 2008, "Monetary Policy and Distribution," Journal of Monetary Economics, Vol. 55, No. 6, pp. 1038-1053.

Woo, Jaejoon, Elva Bova, Tidiane Kinda, and Sophia Zhang, 2013, "Distributional Consequences of Fiscal Consolidation and the Role of Fiscal Policy: What do the Data Say?" IMF Working Paper No. 13/195, (Washington, DC, International Monetary Fund).

World Bank, 2008, "Finance for All? Policies and Pitfalls in Expanding Access," World Bank Policy Research Report.

Wynne, Mark A., 2008, "Core Inflation: A Review of Some Conceptual Issues," Federal Reserve Bank of St. Louis Review, Vol. 90, No.3, Part 2, pp. 205-28. 